\title{
INTRAOPERATIVE PHOTODYNAMIC THERAPY IN GASTRIC CANCER PATIENTS
}

\author{
Filonenko E.V., Kaprin A.D., Suleymanov E.A., Urlova A.N., Khomyakov V.M., \\ Vashakmadze L.A., Sokolov V.V., Kirillov N.V. \\ National Medical Research Radiological Centre of the Ministry of Health \\ of the Russian Federation, Moscow, Russia
}

\begin{abstract}
Results of intraoperative photodynamic therapy (IOPDT) in patients with gastric cancer are represented in the article. The study included 240 patients with gastric cancer stage II-IV (T3-4NO-3MO-1) with evident or suspected peritoneal dissemination who underwent examination and treatment in P.Herzen Moscow Oncology Research Institute. The group 1, the study group, included 140 patients who underwent nominally curative or palliative surgery for locally advanced and disseminated gastric cancer with IOPDT as additional intraoperative intervention for antiblastics and cancer treatment. The group 2, the control group, included 100 patients who also underwent nominally curative or palliative surgery (equal to extent of surgery in patients from the study group) for locally advanced and disseminated gastric cancer and no intraoperative implication of physical or chemical treatment methods. IOPDT did not worsen a course of early post-operative period, did not impact on severity of post-operative complications and was not associated with increase of post-operative mortality. IOPDT allowed for improvement of 1-year and 3-year disease-specific survival rates: by $16.1 \%$ and $16.7 \%$, respectively. For nominally curative resections, median survival, 1-year and 3-year disease-specific survival rates were improved by 14 months, 17.8\% and 31.3\%, respectively. For R1, R2 resections, IOPDT improved 1-year disease-specific survival rates by $16.4 \%$. Additionally, for nominally curative resections IOPDT did not increase the recurrence rate and improved median recurrence-free survival, 1-year and 3-year recurrence-free survival rates by 16 months, $27.2 \%$ and $25.4 \%$, respectively.
\end{abstract}

Key words: gastric cancer, peritoneal carcinomatosis, intraoperative photodynamic therapy.

For citations: Filonenko E.V., Kaprin A.D., Suleymanov E.A., Urlova A.N., Khomyakov V.M., Vashakmadze L.A., Sokolov V.V., Kirillov N.V. Intraoperative photodynamic therapy in gastric cancer patients, Biomedical Photonics, 2017, T. 6, No. 4, pp. 4-12.

Contacts: Filonenko E.V., e-mail: derkul23@yandex.ru

\section{ИНТРАОПЕРАЦИОННАЯ ФОТОДИНАМИЧЕСКАЯ ТЕРАПИЯ БОЛЬНЫХ РАКОМ ЖЕЛУДКА}

\author{
Е.В. Филоненко, А.Д. Каприн, Е.А. Сулейманов, А.Н. Урлова, В.М. Хомяков, \\ Л.А. Вашкамадзе, В.В. Соколов, Н.В. Кириллов \\ Национальный медицинский исследовательский радиологический центр \\ Минздрава России, Москва, Россия
}

\section{Резюме}

В статье преАставлены результаты применения интраоперационной фотодинамической терапии (ИОФАТ) у больных раком желудка. В исслеАование включены 240 пациентов раком желудка II-IV стадии (T3-4N0-3М0-1) с наличием или подозрением на перитонеальную Аиссеминацию, которым в МнИОИ им. П.А. Герцена были проведены обследование и лечение. В первую, основную группу включено 140 больных, которым выполнены условно-радикальные или паляиативные операции по поводу местно-распространенного и Аиссеминированного рака желудка с применением в качестве метода Аополнительного интраоперационного возАействия сцелью интраоперационнойантибластики ипротивоопухолевого возАействия - ИОФАТ. Вторую, контрольную группу составили 100 больных, которым были выполнены также условно-радикальные и паллиативные операции (по объему соответствующие хирургическим вмешательствам у больных основной группы) по поводу местно-распространенного и Аиссеминированного рака желудка без интраоперационного применения физических или химических методов воздействия. ИОФАТ не ухудшила течение раннего послеоперационного периоАа, не влияла на тяжесть послеоперационных осложнений и не ассоциирована с увеличением послеоперационной летальности. ПровеАение ИОФАТ позволило улучшить показатели 1-летней и 3-летней общей специфической выживаемости: на 16,1\% и 16,7\%, соответственно. При условно-радикальных операциях медиану выживаемости на 14 мес, показатели 1-летней и 3-летней общей специфической выживаемости - на 17,8\% и 31,3\%, соответственно. При операциях в объеме R1, R2 провеАение ИОФАТ улучшило 1-летнюю общую специфическую выживаемость на $16,4 \%$. Кроме того, при условно-раАикальных операциях провеАение ИОФАТ не увеличило частоту рециАивов и улучшило 
медиану безрециливной выживаемости на 16 мес, показатели 1-летней и 3-летней безрециливной выживаемости - на 27,2\% и $25,4 \%$, соответственно.

Ключевые слова: рак желудка, канцероматоз брюшины, интраоперационная фотодинамическая терапия.

Для цитирования: Filonenko E.V., Kaprin A.D., Suleymanov E.A., Urlova A.N., Khomyakov V.M., Vashakmadze L.A., Sokolov V.V., Kirillov N.V. Intraoperative photodynamic therapy in gastric cancer patients // Biomedical Photonics. - 2017. - T. 6, № 4. - C. 4-12.

Контакты: Филоненко E.B., e-mail: derkul23@yandex.ru

\section{Introduction}

Gastric cancer is one of the most common cancer digestive tract. In 2015 in Russia in structure of oncological diseases this pathological condition occupied 6th place (6.7\%) after cancer of skin, breast and lung [1]. For gastric cancer peritoneal carcinomatosis is the most common type of metastasis $[2,3,4]$ with incidence of $30-40 \%$ and median survival no more than 3.1 months without treatment [5].

The main method of treatment of resectable gastric cancer stage I-IV is curative surgery aimed at removal of primary tumor and all loco-regional metastases [6-9]. However, even for macroscopically complete cytoreduction the possibility of tumor cells diffusion over peritoneum cannot be excluded [10]; consequently surgical methods should be combined with additional antitumor methods. Considering disadvantages of systemic chemotherapy combined with cytoreductive resections for peritoneal carcinomatosis, there is necessity for development of new antitumor methods aimed at not only prevention of tumor cells from spreading over peritoneum but also at destruction of tumor cells. One of the promising directions is photodynamic therapy (PDT).

Results of IOPDT in patients with gastric cancer are represented in the article.

\section{Materials and methods}

The study included 240 patients with gastric cancer stage II-IV (T3-4N0-3M0-1) with evident or suspected peritoneal dissemination who underwent examination and treatment in P. Herzen Moscow Oncology Research Institute from 2005 to 2012. In all patients gastric tumor invaded to serosa and infiltrated adjacent organs and structures with no distant hematogenous and extraperitoneal lymphogenous metastases.

The group 1, the study group, included 140 patients who underwent nominally curative or palliative surgery for locally advanced and disseminated gastric cancer with IOPDT as additional intraoperative intervention for antiblastics and cancer treatment. The group 2, the control group, included 100 patients who also underwent nominally curative or palliative surgery (equal to extent of surgery in patients from the study group) for locally advanced and disseminated gastric cancer and no intraoperative implication of physical or chemical treatment methods.

The study group included $83(59.3 \%)$ men and 57 (40.7\%) women, the control group - 61 (61\%) men and 39 (39\%) women. There were no differences in the gender distribution between groups (F-test, $\chi^{2}=0.07 ; p=0.79$ ).

The age of patients accounted from 20 to 73 y.o. The minimal age in the study group and in the control group was 20 and 27 y.o., respectively; the maximal age -72 and 73 y.o., respectively. The average age in the study group was $54.4 \pm 11.1$ y.o., in the control group $-57.1 \pm 11.2$ y.o. More than a half of patients (133 patients $(55.5 \%)$ ) were in socially active age group of 20-59 y.o. There were no differences by age between groups (t-test, $\mathrm{p}=0.95$ ).

According to full examination data, $180(75 \%)$ of 240 patients had different co-morbidity: 111 (79.3\%) patients in the study group and $69(69 \%)$ patients in the control group. There were no differences in the co-morbidity rate and structure between groups ( $F$-test, $x^{2}=3.29 ; p=0.07$ ).

The clinical diagnosis according to international TNM staging system (6th ed.) was assigned in all patients after standard examination. Forthestudygroup, stagell(T3NOMO) was in 17 (12.1\%) patients, stage IIIA (T3N1MO, T4NOMO) - in $21(15 \%)$, stage IIIB (T3N2M0) - in $18(12.9 \%)$ and stage IV (T3N0-3M0-1; T4N1-3M0-1) - in $84(60 \%)$. For the control group, stage II (T3NOMO) was in 13 (13\%) patients, stage IIIA (T3N1M0, T4NOMO) - in 18 (18\%), stage IIIB (T3N2M0) - in 15 (15\%) and stage IV (T3NO-3MO-1; T4N1-3MO-1) - in 54 (54\%). In the study and control groups the majority of patients had gastric cancer stage IV $-60 \%$ n $54 \%$, respectively. There was no difference in stage distribution between groups (F-test, for stage II $-p=0.49$; for stage IIIA $-p=0.32$; for stage IIIB $\mathrm{p}=0.39$; for stage IV $-\mathrm{p}=0.21$ ).

According to full examination data in the study and control groups, involvement of one portion of stomach was diagnosed in $32(22.9 \%)$ and $28(28 \%)$ patients, subtotal involvement - in $77(55 \%)$ and in 63 (63\%), total involvement - in 31 (22.1\%) and in 19 (19\%), respectively. There was no difference in tumor location in stomach between groups (F-test, for lower third involvement (antral portion) $-p=0.25$, middle third (body of stomach) $-p=0.31$, upper third (cardiac portion) $-p=0.39$, for subtotal involvement $p=0.43$, for total involvement $-p=0.34$ ).

According to histological data in the study group, well differentiated adenocarcinoma was diagnosed in 2 (1.4\%) patients, moderately differentiated adenocarcinoma in $12(8.6 \%)$, poorly differentiated adenocarcinoma - in $31(22.1 \%)$, signet-ring cell carcinoma - in 40 (28.6\%), combination of signet-ring cell carcinoma with adenocarcinoma - in 55 (39.3\%). For the control group, well differen- 
tiated adenocarcinoma was diagnosed in 2 (2\%) patients, moderately differentiated adenocarcinoma - in $14(14 \%)$, poorly differentiated adenocarcinoma - in 20 (20\%), signet-ring cell carcinoma - in $22(22 \%)$, combination of signet-ring cell carcinoma with adenocarcinoma - in 42 (42\%).Thus, the study and control groups had predominately a combination of signet-ring cell carcinoma with adenocarcinoma (39.3\% and $42 \%$, respectively). There was no difference in morphological diagnosis between groups (F-test; well differentiated adenocarcinoma $p=0.55$; moderately differentiated adenocarcinoma $p=0.13$; poorly differentiated adenocarcinoma $-p=0.41$; signet-ring cell carcinoma $-p=0.16$; combination of signet-ring cell carcinoma with adenocarcinoma $-p=0.39$ ).

\section{Intraoperative photodynamic therapy technique}

For PDT we used photosensitizer fotogem (produced by "Fotogem", Russia), a hematoporphyrin derivative. Fotogem was administered intravenously at a dose of 2.5 $\mathrm{mg} / \mathrm{kg}$ body weight $48 \mathrm{~h}$ before surgery. Patients kept light regimen for 3-4 weeks after injection.

Surgical step was performed according to tumor distribution. If applicable, complete removal of primary tumor and all peritoneal metastases was done, where definitive treatment was impossible, palliative surgery with removal of primary tumor and maximal volume of peritoneal dissemination was carried out.

For both scenarios, IOPDT session was performed after completion of surgical step with sequential polypositional irradiation of all regions of parietal peritoneum at a dose of $6-10 \mathrm{~J} / \mathrm{cm}^{2}$ (Fig. 1). Exposure of visceral peritoneum was carried out by scattering irradiation and irradiation from a source of incoherent emission - operating lamp - for the duration of surgical procedure.

\section{Results}

Efficacy of IOPDT in patients with gastric cancer was analyzed by comparing results of treatment in the study and control groups. For this purpose completeness of cytoreduction, rate and profile of post-operative complications, mortality in early post-operative period and long-term results were assessed.

\section{Characteristics of the surgical step}

All patients had extended and combined surgery. The duration of surgical step accounted from 3 to $6.5 \mathrm{~h}$.

The curative potential of gastric surgery was characterized using Japanese Classification of Gastric Carcinoma, JGCA (1998) [11]. According to this classification 3 types of resections are defined: $A, B$ and $C$. Resection $A$ implies curative surgery and appropriate for primary tumor T1 or $\mathrm{T} 2$ and for stage $\mathrm{MO}(\mathrm{HO}$ - no liver metastases, $\mathrm{PO}$ - no dissemination); N0 treated by D1, D2, D3 lymphadenectomy; N1 - D2, D3 lymphadenectomy; this type of resection is characterized by Cyt 0 - no tumor cells in peritoneal

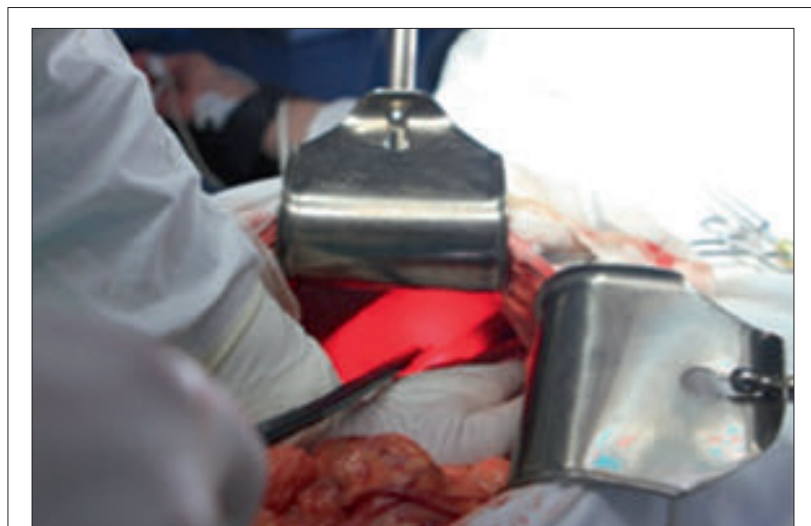

a

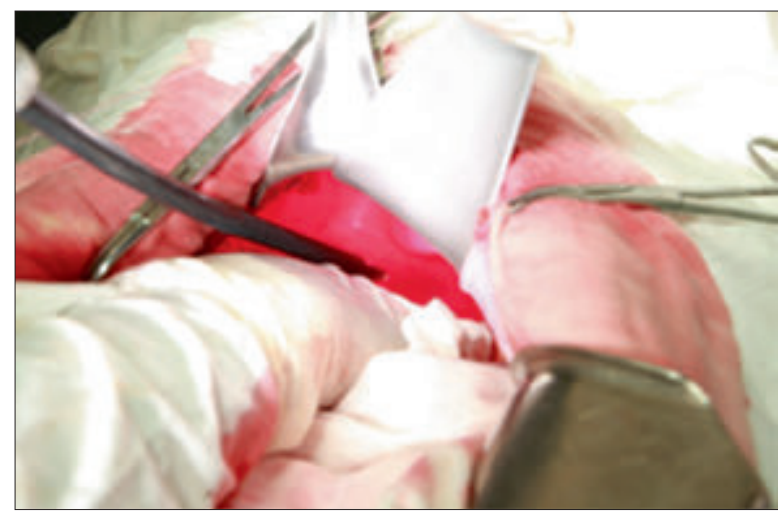

b

Fig. 1. IOPDT session:

a -irradiation of upper region peritoneum;

b - irradiation of pelvic peritoneum

Рис. 1. Сеанс ИОФДТ:

а - облучение брюшины верхних отделов

брюшной полости;

б - облучение брюшины малого таза

lavage, and also by proximal and distal margins clearance more than $10 \mathrm{~mm}$. Resection $B$ implies resections with no residual disease (R0) but not fulfilling criteria for "Resection A". This type of resection was defined as nominally curative surgery. For resection $C$, there is micro (R1) or macro (R2) residual tumor, this type is equivalent to palliative surgery. If unresectable tumor is detected during the surgery and surgery is terminated on this step this surgical intervention is defined as exploratory surgery. There were no resections $A$ and no exploratory surgeries in our study. Distribution of patients according to curative potential of gastric surgery is represented in table 1.

For the study group, 78 (55.7\%) patients underwent nominally curative resections (R0), 62 (44.3\%) patients had palliative surgery (R1 - in 17 (12.2\%), R2 - in 45 (32.1\%) patients). For the control group, 58 (58\%) patients underwent nominally curative resections (R0), $42(42 \%)$ patients had palliative surgery (R1 - in 7 (7\%), R2 - in 35 (35\%) patients).

Thus, in the study and control groups rates of resections R0 and R1, R2 were approximately equal (rates of 
Table 1

Distribution of patients according to curative potential of gastric surgery

Таблица 1

Распределение больных в зависимости от радикальности выполненной операции

\begin{tabular}{|c|c|c|c|c|}
\hline \multirow{3}{*}{$\begin{array}{l}\text { Group of patients } \\
\text { Группа больных }\end{array}$} & \multicolumn{3}{|c|}{$\begin{array}{l}\text { Type of resection } \\
\text { Тип операции }\end{array}$} & \multirow{3}{*}{ 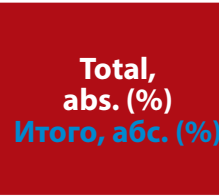 } \\
\hline & B & \multicolumn{2}{|c|}{ C } & \\
\hline & RO & R1 & $\mathbf{R} 2$ & \\
\hline $\begin{array}{l}\text { Study group, abs. (\%) } \\
\text { Основная, абс. (\%) }\end{array}$ & 78 (55.7\%) & $17(12.2 \%)$ & 45 (32.1\%) & 140 (100\%) \\
\hline $\begin{array}{l}\text { Control group, abs. (\%) } \\
\text { Контрольная, абс. (\%) }\end{array}$ & $58(58 \%)$ & 7 (7\%) & $35(35 \%)$ & $100(100 \%)$ \\
\hline $\begin{array}{l}\text { Total, abs. (\%) } \\
\text { Bcero, абc. (\%) }\end{array}$ & 136 (56.7\%) & $24(10 \%)$ & $80(33.3 \%)$ & 240 (100\%) \\
\hline
\end{tabular}

resection R0 accounted for $55.7 \%$ and $58 \%$, resection R1, R2 - $44.3 \%$ and $42 \%$, respectively). There was no difference in curative potential of gastric surgery between groups (F-test, for $\mathrm{R} 0 \mathrm{p}=0.41$; for $\mathrm{R} 1 \mathrm{p}=0.14$; for $\mathrm{R} 2 \mathrm{p}=0.37$ ).

Distribution of patients according to the extent of surgery is represented in table 2 . Distal subtotal gastric resection was performed in $17(12.2 \%)$ patients from the study group and in $12(12 \%)$ patients from the control group, gastrectomy - in $37(26.4 \%)$ and 27 (27\%), combined resections - in $86(61.4 \%)$ and 61 (61\%), respectively.

In the study and control groups the majority of surgical procedures were combined resections $(61.4 \%$ and $61 \%$, respectively) due to extent of tumor. Gastrectomy was combined with resection of transverse colon, pancreas, liver, diaphragm, spleen. D2, D3 lymphadenectomy was performed. There was no difference in extent of surgery between groups (F-test, for distal subtotal gastric resection $-p=0.57$; for gastrectomy $-p=0.52$; for combined resection $-p=0.53$ ).

\section{Early post-operative period}

To compare the study group with the control group for course of post-operative period we used follow- ing criteria: rate of acute post-operative complications, profile of acute post-operative complications, grade of acute post-operative complications, necessity for surgical treatment of complications and mortality. Chosen criteria allow assessing feasibility of IOPDT with no risk of worsening of early results of treatment.

Acute post-operative complications were in $32(22.9 \%)$ of 140 patients in the study group and in 26 (26\%) of 100 patients in the control group. Statistical analysis of rates of post-operative complications in the study and control groups with F-test showed no differences ( $p=0.32$ ).

Patients in the study group had following acute postoperative complications: necrotizing pancreatitis - 19 (13.6\%), esophago-intestinal anastomotic leakage - 4 (2.9\%), colon anastomotic leakage - $1(0.7 \%)$, acute intestinal obstruction - $4(2.9 \%)$, postoperative wound infection - $3(2.1 \%)$, pleuritis - 9 (6.4\%), pneumonia - $5(3.6 \%)$, pulmonary thromboembolism - 2 (1.4\%). For the control group necrotizing pancreatitis was in 14 (14\%) patients, esophago-intestinal anastomotic leakage - $1(1 \%)$, acute intestinal obstruction - $2(2 \%)$, postoperative wound infection - 2 (2\%), pleuritis - $5(5 \%)$, pneumonia - $3(3 \%)$, pulmonary thromboembolism $-2(2 \%)$, acute myocardial

\section{Table 2}

Distribution of patients according to the extent of surgery

Таблица 2

Распределение больных в зависимости от объема операции

\begin{tabular}{|c|c|c|c|c|}
\hline \multirow[b]{2}{*}{$\begin{array}{l}\text { Group of patients } \\
\text { Группа больных }\end{array}$} & \multicolumn{3}{|c|}{ Type of operative procedure } & \multirow[b]{2}{*}{$\begin{array}{l}\text { Total, abs. (\%) } \\
\text { Иroro, aбc. } \\
(\%)\end{array}$} \\
\hline & $\begin{array}{c}\text { Distal subtotal gastric resection } \\
\text { Дистальная субтотальная } \\
\text { резекция желудка }\end{array}$ & $\begin{array}{l}\text { Gastrectomy } \\
\text { Гастрэктомия }\end{array}$ & $\begin{array}{l}\text { Combined resection } \\
\text { Комбинированная } \\
\text { гастрәктомия }\end{array}$ & \\
\hline $\begin{array}{l}\text { Study group, abs. (\%) } \\
\text { Основная, абс. (\%) }\end{array}$ & $17(12.2 \%)$ & $37(26.4 \%)$ & $86(61.4 \%)$ & $140(100 \%)$ \\
\hline $\begin{array}{l}\text { Control group, abs. (\%) } \\
\text { Контрольная, абс. (\%) }\end{array}$ & $12(12 \%)$ & $27(27 \%)$ & $61(61 \%)$ & $100(100 \%)$ \\
\hline $\begin{array}{l}\text { Total, abs. (\%) } \\
\text { Всего, абс. (\%) }\end{array}$ & 29 (12.1\%) & $64(26.7 \%)$ & 147 (61.3\%) & 240 (100\%) \\
\hline
\end{tabular}


infarction - 1 (1\%), intra-abdominal hemorrhage - 1 (1\%).

Thus, patients in the study and control groups most commonly had necrotizing pancreatitis and inflammation in lungs and pleura (13.8\% and $9.1 \%$, respectively) (table 3 ). Such profile of post-operative complications is due to the fact, that the majority of surgical procedures in the study and control groups were combined resections $(61.4 \%$ and $61 \%$, respectively). Additionally, pleuritis and pneumonia was associated with other types of complications (necrotizing pancreatitis, esophago-intestinal anastomotic leakage etc.) in the study and control groups.

In the profile of acute post-operative complications there was no colon anastomotic leakage in the control group ( $p=0.58)$ comparing with the study group, but there were acute myocardial infarction $(p=0.42)$ and intraabdominal hemorrhage $(p=0.42)$. Statistic analysis using F-test showed no significant differences in the profile of acute post-operative complications. The $p$-values for necrotizing pancreatitis, anastomotic leakage, acute intestinal obstruction, inflammation in lungs and pleura, thrombosis, wound infection when compared control group vs. IOPDT were $0.53,0.21,0.51,0.39,0.46,0.65$, respectively.

Surgical treatment for early post-operative complications was performed in 9 (28.1\%) of 32 patients of the study group and in 8 (30.8\%) of 26 patients of the control group. Statistic analysis of rates of surgeries for early post-operative complications using F-test showed no significant differences between the study and control groups $(p=0.52)$.

There were $3(2.1 \%)$ deaths in the study group and 3 (3\%) patients died in the control group. Causes of death were pulmonary thromboembolism and necrotizing pancreatitis. Statistic analysis of mortality using F-test showed no significant differences between the study and control groups $(p=0.32)$.

\section{Long-term results}

To evaluate efficiency of IOPDT long-term results in the study and control group were analyzed. For disease-

\section{Table 3}

Profile of acute post-operative complications

Таблица 3

Структура ранних послеоперационных осложнений

\begin{tabular}{|c|c|c|c|}
\hline $\begin{array}{l}\text { Type of complication } \\
\text { Вид осложнений }\end{array}$ & $\begin{array}{l}\text { Study group, abs. (\% of } \\
\text { total number of patients in } \\
\text { the group) } \\
\text { Основная группа, абс. ( } \% \\
\text { от общего количества } \\
\text { пациентов в группе) }\end{array}$ & $\begin{array}{l}\text { Control group, abs. (\% of } \\
\text { total number of patients } \\
\text { in the group) } \\
\text { Контрольная группа, } \\
\text { абс. (\% от общего } \\
\text { количества пациентов } \\
\text { в группе) }\end{array}$ & $\begin{array}{c}\text { Total, abs. (\% of } \\
\text { total number of } \\
\text { patients) } \\
\text { Итого, a } 6 \mathrm{c} . \\
\text { (\% от общего } \\
\text { количества } \\
\text { пациентов) }\end{array}$ \\
\hline $\begin{array}{l}\text { Necrotizing pancreatitis } \\
\text { Панкреонекроз }\end{array}$ & 19 (13.6\%) & $14(14 \%)$ & 33 (13.8\%) \\
\hline $\begin{array}{l}\text { Esophago-intestinal anastomotic leakage } \\
\text { Несостоятельность пищеводно- } \\
\text { кишечного анастомоза }\end{array}$ & 4 (2.9\%) & $1(1 \%)$ & $5(2.1 \%)$ \\
\hline $\begin{array}{l}\text { Colon anastomotic leakage } \\
\text { Несостоятельность толстокишечного } \\
\text { анастомоза }\end{array}$ & $1(0.7 \%)$ & 0 & $1(0.4 \%)$ \\
\hline $\begin{array}{l}\text { Acute intestinal obstruction } \\
\text { Острая кишечная непроходимость }\end{array}$ & 4 (2.9\%) & $2(2 \%)$ & $6(2.5 \%)$ \\
\hline $\begin{array}{l}\text { Postoperative wound infection } \\
\text { Нагноение послеоперационной раны }\end{array}$ & $3(2.1 \%)$ & $2(2 \%)$ & $5(2.1 \%)$ \\
\hline $\begin{array}{l}\text { Pleuritis } \\
\text { Плеврит }\end{array}$ & $9(6.4 \%)$ & $5(5 \%)$ & $14(5.8 \%)$ \\
\hline $\begin{array}{l}\text { Pneumonia } \\
\text { Пневмония }\end{array}$ & $5(3.6 \%)$ & $3(3 \%)$ & $8(3.3 \%)$ \\
\hline $\begin{array}{l}\text { Pulmonary thromboembolism } \\
\text { Тромбоэмболия легочной артерии }\end{array}$ & $2(1.4 \%)$ & $2(2 \%)$ & $4(1.7 \%)$ \\
\hline $\begin{array}{l}\text { Acute myocardial infarction } \\
\text { Острый инфаркт миокарда }\end{array}$ & 0 & $1(1 \%)$ & $1(0.4 \%)$ \\
\hline $\begin{array}{l}\text { Intra-abdominal hemorrhage } \\
\text { Внутрибрюшное кровотечение }\end{array}$ & 0 & $1(1 \%)$ & $1(0.4 \%)$ \\
\hline $\begin{array}{l}\text { Total number of patients with } \\
\text { complications, abs. (\% of total number of } \\
\text { patients in the group) } \\
\text { Всего пациентов с осложнениями, } \\
\text { абс. (\% от общего количества пациентов } \\
\text { в группе) }\end{array}$ & 32 (22.9\%) & $26(26 \%)$ & $58(24.2 \%)$ \\
\hline
\end{tabular}


specific survival the end-point was a death of a patient from cancer disease. For recurrence-free survival the end-point was a recurrence or progression of cancer in patients who underwent nominally curative surgery. Patients who died in early post-operative period from complications $(n=6)$ were excluded from the analysis. Long-term results were obtained in $97.5 \%$ of patients.

For the study group, maximal follow-up period was
72 months with median survival of 20 months. One-year disease-specific survival accounted for $70.6 \pm 3.9 \%$, 3-year $39.6 \pm 4.3 \%$. For the control group, maximal follow-up period was 58 months with median survival of 13 months. One-year disease-specific survival accounted for $54.5 \pm 5.1 \%$, 3 -year $-22.9 \pm 4.4 \%$. Statistic analysis using Log-Rang Test showed no significant difference between groups but data tended toward significance ( $p=0.07$ ) (Fig. 2).

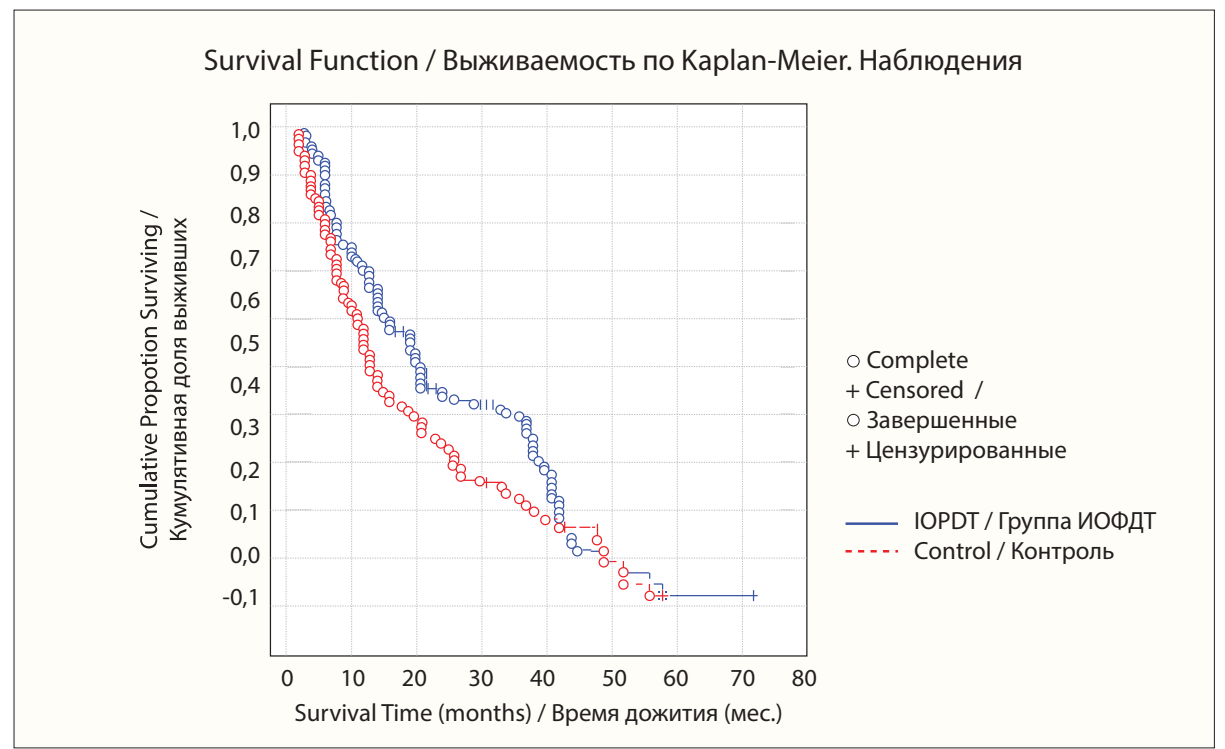

Fig. 2. Disease-specific survival in the study and control groups

Рис. 2. Общая специфическая выживаемость в основной и контрольной группах

For the study group, in patients with nominally curative resections maximal follow-up period was 72 months with median survival of 41 months. One-year disease-specific survival accounted for $96.1 \pm 2.2 \%$, 3 -year $-71.4 \pm 5.5 \%$. For the control group, maximal fol- low-up period was 58 months with median survival of 27 months. One-year disease-specific survival accounted for $78.3 \pm 5.5 \%$, 3-year $-40.1 \pm 6.8 \%$. Statistic analysis using Log-Rang Test showed significant difference between groups ( $p=0.05$ ) (Fig. 3).

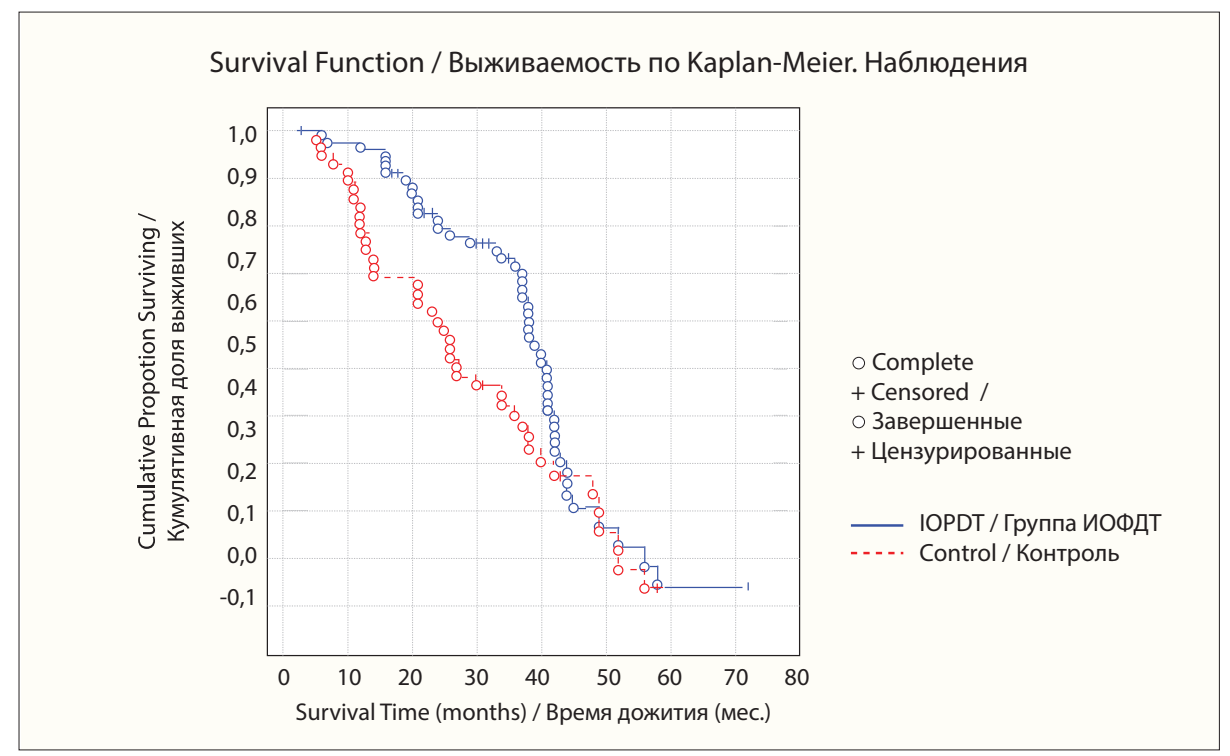

Fig. 3. Disease-specific survival in the study and control groups in patients with nominally curative resections

Рис. 3. Общая специфическая выживаемость в основной и контрольной группах при условно-радикальных операциях 
For the study group, in patients with R1, R2 resections maximal follow-up period was 21 months with median survival of 8 months. One-year disease-specific survival accounted for $38.3 \pm 6.3 \%$. For the control group, maximal follow-up period was 20 months with median survival of 7 months. One-year disease-specific survival accounted for $21.9 \pm 6.4 \%$. Statistic analysis using Log-Rang Test showed significant difference between groups ( $p=0.04$ ) (Fig. 4).

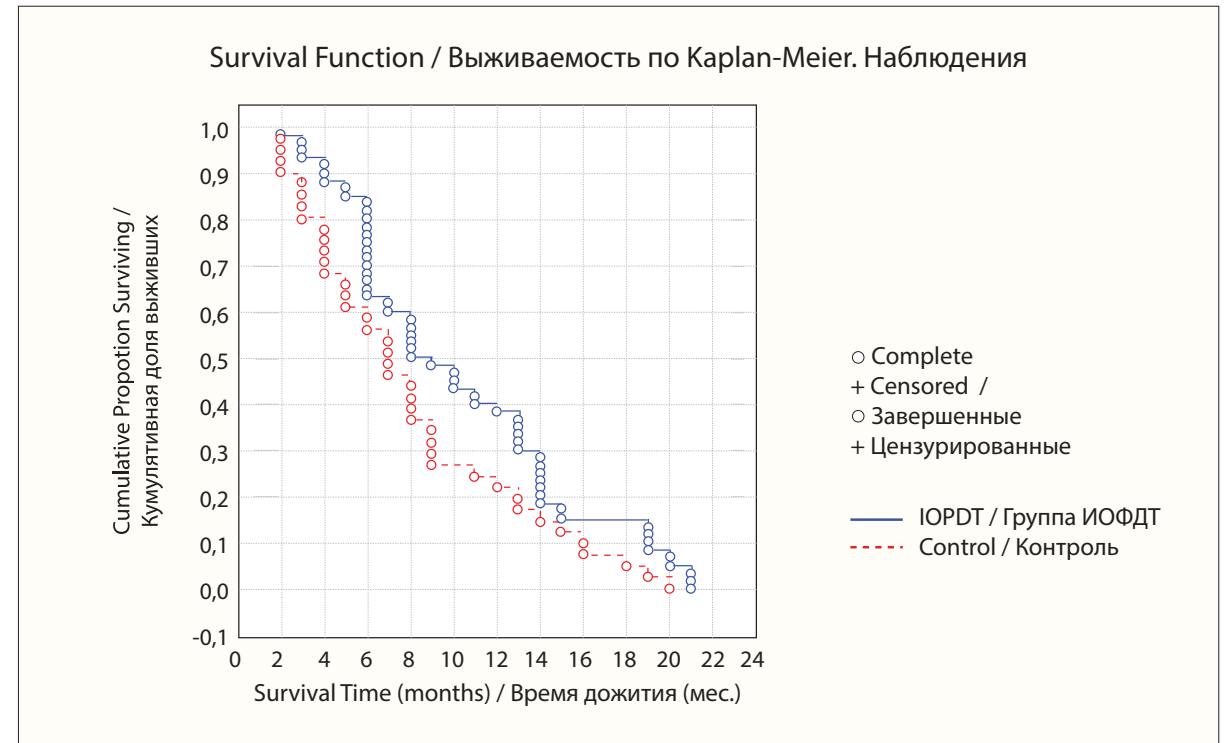

Fig. 4. Disease-specific survival in the study and control groups in patients with R1, R2 resections

Рис. 4. Общая специфическая выживаемость в основной и контрольной группах при операциях R1 и R2

For the study group, in patients with nominally curative resections the recurrence diagnosed in $52(66.7 \%)$ of 78 patients, in the control group - in 43 (74.1\%) of 58. Statistic analysis using Log-Rang Test showed no significant difference between groups ( $F$-test, $\mathrm{p}=0.23$ ).

For the study group, in patients with nominally curative resections maximal follow-up recurrence-free period accounted for 72 months with median recurrence-free survival of 37 months. One-year recurrence-free survival accounted for $89.4 \pm 3.5 \%$, 3-year $-51.9 \pm 6.1 \%$. For the control group, maximal follow-up recurrence-free period accounted for 58 months with median recurrence-free survival of 21 months. One-year recurrence-free survival accounted for $62.2 \pm 6.5 \%$, 3-year - $26.5 \pm 6.2 \%$. Statistic analysis using Log-Rang Test showed significant difference between groups $(p=0.03)$ (Fig. 5).

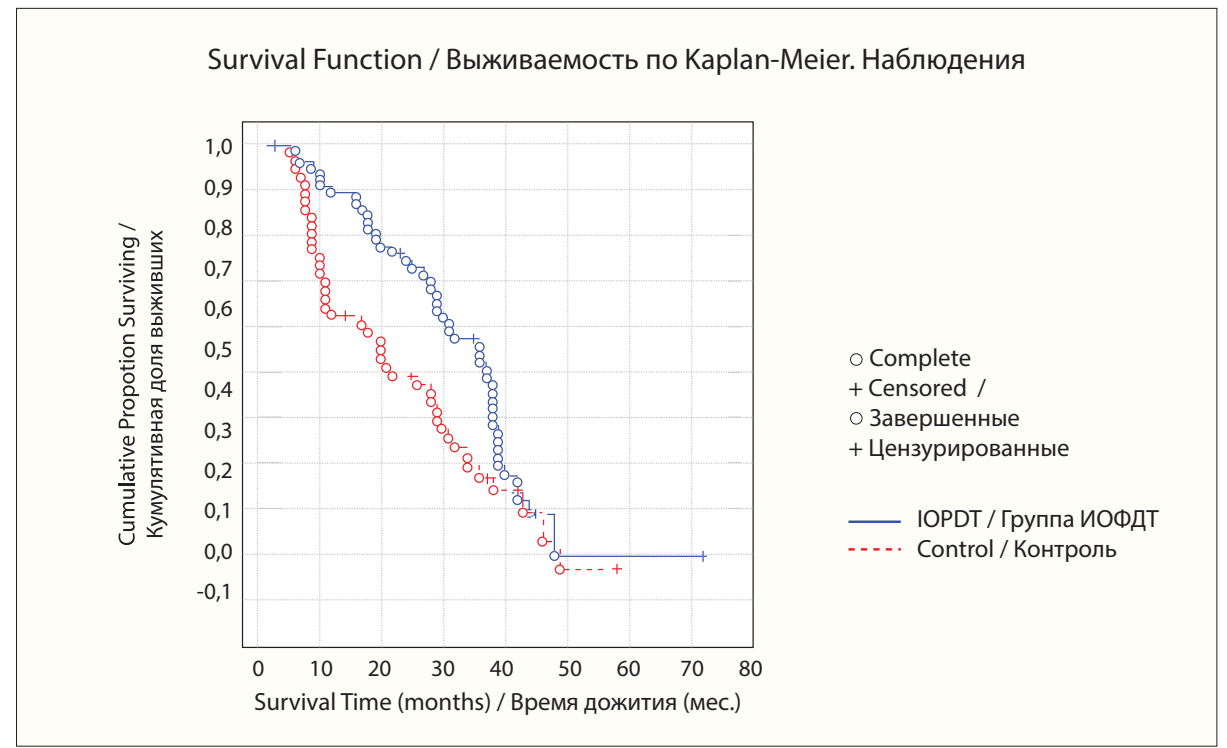

Fig. 5. Recurrence-free survival in the study and control groups in patients with nominally curative resections Рис. 5. Безрецидивная выживаемость в основной и контрольной группах при условно-радикальных операциях 


\section{Discussion}

Historically methods of additional antitumor methods developed from irrigation with solutions and instillation of radioactive substances to implication of photosensitizing agents for photodynamic destruction of tumor implants and also to implication chemotherapeutical agents injected to peritoneum at doses exceeding standard ones for systemic treatment [12]. Toxicity of intraperitoneal chemotherapy may be high and efficiency of disease control depends considerably on histological structure of the tumor $[13,14]$. Despite the active development of intraperitoneal chemotherapy treatment results in patients with gastric cancer with peritoneal carcinomatosis remain unsatisfactory: post-operative complications are up to $40 \%$, post-operative mortality $-20 \%$, median survival rates - 6-15.4 months, 1-year survival rates by Kaplan-Meier - up to $50.7 \%$ [15-17].

In our study, IOPDT did not worsen a course of early post-operative period, did not impact on severity of post-operative complications and was not associated with increase of post-operative mortality when comparing the study and control groups $(p=0.32)$. IOPDT allowed for improvement of median survival, 1-year and 3-year disease-specific survival rates: by 7 months, $16.1 \%$ and $16.7 \%$, respectively $(p=0.07)$. For nominally curative resections, median survival, 1-year and 3-year diseasespecific survival rates were improved by 14 months, $17.8 \%$ and $31.3 \%$, respectively $(p=0.05)$. For $R 1, R 2$ resections, IOPDT improved median survival and 1-year diseasespecific survival rates by 1 month and $16.4 \%(p=0.04)$, respectively. Additionally, for nominally curative resections IOPDT did not increase the recurrence rate $(p=0.23)$ and improved median recurrence-free survival, 1-year and 3-year recurrence-free survival rates by 16 months, $27.2 \%$ and $25.4 \%$, respectively $(p=0.03)$.

\section{Conclusion}

Intraoperative photodynamic therapy is an efficient and safe method of intraoperative intervention in patients with gastric cancer with high risk or confirmed peritoneal dissemination. Widespread implementation of the method into clinical practice will promote improvement of oncological treatment results in this group of patients.

\section{ЛИТЕРАТУРА}

1. Злокачественные новообразования в России в 2015 году (смертность и заболеваемость) // под ред. А.Д. Каприна, В.В. Старинского, Г.В. Петровой. - М.: ФГБУ «МНИОИ им. П.А. Герцена» Минздрава России, 2017. - 250 с.

2. Филоненко Е.В., Вашакмадзе Л.А., Кириллов Н.В., Хомяков В.М. Интраоперационная фотодинамическая терапия в хирургическом лечении рака желудка (обзор литературы) // Сибирский онкологический журнал. - 2012. - № 2. - С. 84-89.

3. Sugarbaker P.H., Cunliffe W.J., Belliveau J., et al. Rationale for integrating early postoperative intraperitoneal chemotherapy into the surgical treatment of gastrointestinal cancer // Semin Oncol. 1989. - Vol. 16 (4 Suppl 6). - P. 83-97.

4. Bando E., Yonemura Y., Takeshita Y., et al. Intraoperative lavage for cytological examination in 1,297 patients with gastric carcinoma // Am J Surg. - 1999. - Vol. 178(3). - P. 256-262.

5. Соломенный С.В., Минигазимов Р.С. Перитонеальный канцероматоз. Обзор мирового опыта // Креативная хирургия и онкология. - 2013. - № 4. - С. 115-119.

6. Гусейнов А.3., Истомин Д.А., Гусейнов Т.А. Объем оперативных вмешательств при раке желудка: современные тенденции // Вестник новых медицинских технологий. Электронное издание. - 2013. - № 1. - С. 165.

7. Загайнов А.С., Зубков Р.А., Дворниченко В.В. и др. Непосредственные результаты применения расширенной лимфодиссекции при распространённом раке желудка // Сибирский медицинский журнал. - 2014. - Т. 131, № 8. - С. 64-67.

8. Тер-Ованесов М.Д., Левицкий А.В., Габоян А.С. и др. Рак проксимального отдела желудка: объем хирургического вмешательства как фактор прогноза // Альманах мировой науки. - 2015. № 1-1 (1). - C. 68-70.

\section{REFERENCES}

1. Zlokachestvennye novoobrazovaniya v Rossii v 2015 godu (zabolevaemost' ismertnost') [Malignant neoplasms in Russia in 2015 (incidence and mortality)], by eds Kaprin A.D., Starinskii V.V., Petrova G.V. Moscow, MNIOI im. P.A. Gertsena Publ., 2017. 250 p.

2. Filonenko E.V. Vashakmadze L.A. Kirillov N.V. Khomyakov V.M. Intraoperative photodynamic therapy in surgical treatment of gastric cancer (literature review), Sibirskii onkologicheskii zhurnal, 2012, No. 2, pp. 84-89. (in Russian)

3. Sugarbaker P.H., Cunliffe W.J., Belliveau J., de Bruijn E.A., Graves T., Mullins R.E., Schlag P. Rationale for integrating early postoperative intraperitoneal chemotherapy into the surgical treatment of gastrointestinal cancer, Semin Oncol, 1989, Vol. 16(4 Suppl 6), pp. 83-97.

4. Bando E., Yonemura Y., Takeshita Y., Taniguchi K., Yasui T., Yoshimitsu Y., Fushida S., Fujimura T., Nishimura G., Miwa K. Intraoperative lavage for cytological examination in 1,297 patients with gastric carcinoma, Am J Surg, 1999, Vol. 178(3), pp. 256-262.

5. Solomenny S.V., Minigazimov R.S. Peritoneal carcinomatosis. review of world experience, Kreativnaya khirurgiya i onkologiya, 2013, No. 4, pp. 115-119. (in Russian)

6. Guse'nov A.Z., Istomin D.A., Guseinov T.A. Volume of operative interventions at the gastric cancer: modern tendencities, Vestnik novykh meditsinskikh tekhnologii. Elektronnoe izdanie, 2013, No. 1, p. 165. (In Russian)

7. Zagainov A.S., Zubkov R.A., Dvornichenko V.V., Golodnikov M.A., Gorbanyova O.A The immediate benefits of extended lymph node dissection for advanced gastric cancer, Sibirskii Medicinskii Zhurnal. 2014, Vol. 131, No. 8, pp. 64-67. (in Russian)

8. Ter-Ovanesov M.D., Levickij A.V., Gaboyan A.S., Kukosh M.Yu., Lesnidzeh E.H., Baksiyan G.A. Proximal third gastric carcinoma: 
9. Чернявский А.А., Лавров Н.А., Стражнов А.В., Пенин С.В. Резекционные вмешательства на поджелудочной железе при операциях по поводу рака желудка // Вестник хирургической гастроэнтерологии. - 2013. - № 3. - С. 4-13.

10. Bijelic L., Yan T.D., Sugarbaker P.H. Failure analysis of recurrent disease following complete cytoreduction and perioperative intraperitoneal chemotherapy in patients with peritoneal carcinomatosis from colorectal cancer // Ann. Surg. Oncol. - 2007. - Vol. 14. - P. 2281-2288.

11. Japanese Gastric Cancer Association Gastric. Japanese Classification of Gastric Carcinoma - 2nd English Edition // Cancer. - 1998. Vol. 1. - P. 10-24.

12. Rajeshkumar B.R., Paliwal S., Lambert L., et al. Treatment of peritoneal carcinomatosis with intraperitoneal administration of AdhARF // J Surg Res. - 2015. - Vol. 197(1). - P. 85-90.

13. Chua T.C., Moran B.J., Sugarbaker P.H., et al. Early- and longterm outcome data of patients with pseudomyxoma peritonei from appendiceal origin treated by a strategy of cytoreductive surgery and hyperthermic intraperitoneal chemotherapy // J Clin Oncol. 2012. - Vol. 30. - P. 2449-2456.

14. Glehen O., Kwiatkowski F., Sugarbaker P.H., et al. Cytoreductive surgery combined with perioperative intraperitoneal chemotherapy for the management of peritoneal carcinomatosis from colorectal cancer: a multi-institutional study // J Clin Oncol. 2004. - Vol. 22. - P. 3284-3292.

15. Nadiradze G., Giger-Pabst U., Zieren J., et al. Pressurized intraperitoneal aerosol chemotherapy (PIPAC) with low-dose cisplatin and doxorubicin in gastric peritoneal metastasis // J. Gastrointest. Surg. - 2016. - Vol. 20. - P. 367-373.

16. Тарасов В.А., Виноградова М.В., Ключиков В.3., Беляев А.М. Хирургическое лечение распространенных форм рака желудка // Практ. онкол. - 2001. - № 3(7). - С. 52-58.

17. Каприн А.Д., Соболев Д.Д., Хомяков В.М. и др. Результаты комбинированного лечения больных местно-распространенным и диссеминированным раком желудка с использованием гипертермической интраоперационной внутрибрюшной химиотерапии // Онкология. Журнал им. П.А. Герцена. - 2014. T. 2, № 6. - С. 5-12. extent of surgical resection as prognostic factor, Al'manah mirovo nauki, 2015, No. 1-1(1), pp. 68-70. (in Russian)

9. Chernyavskij A.A., Lavrov N.A., Strazhnov A.V., Penin S.V. Resections on pancreas during surgeries for gastric cancer, Vestnik khirurgicheskoi gastroenterologii, 2013, No. 3, pp. 4-13. (in Russian)

10. Bijelic L., Yan T.D., Sugarbaker P.H. Failure analysis of recurrent disease following complete cytoreduction and perioperative intraperitoneal chemotherapy in patients with peritoneal carcinomatosis from colorectal cancer, Ann. Surg. Oncol., 2007, Vol. 14, pp. 2281-2288.

11. Japanese Gastric Cancer Association Gastric. Japanese Classification of Gastric Carcinoma - 2nd English Edition, Cancer, 1998, Vol. 1, pp. 10-24.

12. Rajeshkumar B.R., Paliwal S., Lambert L., Grossman S.R., Whalen G.F. Treatment of peritoneal carcinomatosis with intraperitoneal administration of Ad-hARF, J Surg Res, 2015, Vol. 197(1), pp. 85-90.

13. Chua T.C., Moran B.J., Sugarbaker P.H., Levine E.A., Glehen O., Gilly F.N., Baratti D., Deraco M., Elias D., Sardi A., Liauw W., Yan T.D., Barrios P., Gómez Portilla A., de Hingh I.H., Ceelen W.P., Pelz J.O., Piso P., González-Moreno S., Van Der Speeten K., Morris D.L. Early- and longterm outcome data of patients with pseudomyxoma peritonei from appendiceal origin treated by a strategy of cytoreductive surgery and hyperthermic intraperitoneal chemotherapy, J Clin Oncol, 2012, Vol. 30, pp. 2449-2456.

14. Glehen O., Kwiatkowski F., Sugarbaker P.H., Elias D., Levine E.A., De Simone M., Barone R., Yonemura Y., Cavaliere F., Quenet F., Gutman M., Tentes A.A., Lorimier G., Bernard J.L., Bereder J.M., Porcheron J., Gomez-Portilla A., Shen P., Deraco M., Rat P. Cytoreductive surgery combined with perioperative intraperitoneal chemotherapy for the management of peritoneal carcinomatosis from colorectal cancer: a multi-institutional study, J Clin Oncol, 2004 Vol. 22, pp. 3284-3292

15. Nadiradze G., Giger-Pabst U., Zieren J., Strumberg D., Solass W., Reymond M.A. Pressurized intraperitoneal aerosol chemotherapy (PIPAC) with low-dose cisplatin and doxorubicin in gastric peritoneal metastasis, J. Gastrointest. Surg., 2016, Vol. 20, pp. 367-373.

16. Tarasov V.A., Vinogradova M.V., Klyuchikov V.Z., Belyaev A.M. Surgical treatment for advanced gastric cancer, Prakticheskaya onkologiya, 2001, Vol. 3(7), pp. 52-58. (In Russian)

17. Kaprin A.D., Sobolev D.D., Khomyakov V.M., Bolotina L.V., Ryabov A.B., Khoronenko V.E. Kolobaev I.V., Shemetova M.M., Kramskaya L.V., Ivanov A.V. Results of combined treatment using hyperthermic intraoperative intraperitoneal chemotherapy in patients with locally advanced and disseminated gastric cancer, Onkologiya. Zhurnal imeni P.A. Gertsena, 2014, Vol. 2, No. 6, pp. 5-12. (in Russian) 